\title{
THE MALONE-KIUTSI REACTIONS IN PREGNANCY AND CANCER *
}

\author{
SAMUEL BERKOWITZ, M.D. \\ NEW YORK
}

Various attempts have been made to simplify the technic of the Abderhalden dialysis test, but without success. Some of the investigators have applied the technic originally described by him with the use of the urine instead of the blood serum. The results have been variable.

The theoretical basis for the use of the urine has been on the supposition that the enzymes which dialyze through a parchment thimble pass through the kidney and are found in the urine (Berman, ${ }^{1}$ Malone ${ }^{2}$ ).

L. M. Warfield ${ }^{3}$ had reported seventeen analyses (Abderhalden method) on urines of pregnant women in which he had obtained positive reactions in all. Fischer ${ }^{4}$ pointed out later that Warfield ${ }^{3}$ had omitted the urine of males and nonpregnant females as controls. Fischer ${ }^{4}$ found that in his laboratory all urines with few exceptions gave a positive ninhydrin reaction. These findings coincide with my observations. He felt that the negative reactions were due to some ninhydrin inhibiting substances, but he did not attempt to explain their nature.

Berman $^{1}$ had reported the dialysis test on ninety-seven urines of pregnancy, forty-eight specimens of gynecologic patients and ten of males. His positive reactions to ninhydrin after incubation were 92 , 89 , and 70 per cent., respectively.

Falls and Welker ${ }^{5}$ in a detailed report stated that amino-acids form an appreciable part of the normal nitrogenous elimination in the urine. They reasoned that if ninhydrin reacted with compounds containing the intact amino group, then all normal urines should react positively with the reagent unless the content of the amino-acids fell below the limits of the delicacy of the reaction.

* Submitted for publication Sept. 22, 1916.

* From the Physiological Chemical Laboratory, Beth Israel Hospital.

* This work was done under the tenure of the Ehrmann Fellowship.

1. Berman, L.: Application of the Ninhydrin Reaction to the Urines and Urinary Dialysates of Pregnant Women, Am. Jour. Obst., 1914, 70, 192.

2. Malone, R. H.: Jour. Am. Med. Assn., 1915, 64, 1651.

3. Warfield, L. M.: Jour. Am. Med. Assn., 1914, 62, 436.

4. Fischer, C. E. M.: Jour. Am. Med. Assn., 1914, 62, 950.

5. Falls, F. H., and Welker, W. H.: Jour. Am. Med. Assn., 1914, 62, 1800. 
In June, 1914, M. Kiutsi ${ }^{6}$ of Japan claimed to have discovered a new modification of the Abderhalden reaction in which he had avoided using dialyzing thimbles, with excellent results. In pregnancy he had "repeated this method hundred times and never missed." Moreover, he stated in a later communication" that "it is not at all difficult with the improved method to diagnose the pregnance in, but two hours after the test began."

He claimed that he could diagnose cancer, tuberculosis, gallbladder disease, appendicitis, retinitis, and choroiditis, and had isolated a ferment for each disease. In other words, a large number of our present common diseases could be diagnosed by laboratory methods alone.

One is impressed in a perusal of his reports by the secrecy of the details of the technic in such an important discovery. In his test for pregnancy he made use of a preparation, called by him "ninserin," as the substrate, but he did not give the details of the preparation.

In view of Malone's results in pregnancy, I made attempts to corroborate his findings and extend the usefulness of the test to cancer. This study covers sixty-seven analyses, including urines of pregnant and nonpregnant women, urines of cancer patients and urines from normal males. The results are discussed in the accompanying tables.

I undertook to determine the following:

1. The preparation of the substrate.

2. The preparation of the urine.

3. The technic of the test.

4. The determination of the period of incubation (Table 1).

5 . The value of the test in pregnancy (Table 2).

6. The value of the test in cancer (Table 3 ).

7. The reaction of the urine of pregnant and cancer patients on both placental and cancer substrates (Tables 3 and 4).

1. Preparation of the Substrates: For the pregnancy test fresh placenta was used, while for the cancer test an adenocarcinoma of the liver was employed. The preparation in both instances was alike.

A fresh placenta was placed in normal saline solution and as much blood forced out of it as possible. It was then divided into small pieces with an ordinary meat chopper, after discarding all the blood vessels and connective tissue, and placed into running tap water for approximately thirty-six hours. The residual tissue appeared snow white. All red pieces and blood clots were removed before boiling in distilled water. Five drops of dilute acetic acid were then added to

6. Kiutsi, M.: Kiutsi's Urindiagnosis by Means of "Filtration Process," June 10, 1914, printed by Bunyeido, Sapporo, Japan.

7. Kiutsi, M.: Kiutsi's Isolation of Protective Ferments and Progress of Filtration Process, Oct. 1, 1914, printed by Bunyeido, Sapporo, Japan. 
the water, as recommended by Abderhalden. It was boiled for five minutes and then washed with distilled water four or five times by shaking with water equal to five times the amount of substrate used; the supernatant fluid was decanted each time. The boiling process was repeated till 5 c.c. of filtered decanted water gave a negative reaction with 1 c.c. of 0.1 per cent. ninhydrin in solution (acetic acid was added only in the first boiling).

The next step consisted in drying the substrate in a water chamber oven at $80 \mathrm{C}$. for four hours and over night at $55 \mathrm{C}$., and then in a desiccator over calcium chlorid for three days. The resulting brown powder was very dry and hard, and was kept in a ground glass stoppered bottle in a dark place. The substrate used in the cancer tests was prepared in the same way.

TABle 1.-Determination of the Period of Incubation*

\begin{tabular}{|c|c|c|c|c|c|c|c|c|c|c|c|}
\hline \multirow{2}{*}{$\begin{array}{c}\text { Speci- } \\
\text { men } \\
\text { Number }\end{array}$} & \multirow{2}{*}{$\begin{array}{l}\text { C.c. } \\
\text { Each } \\
\text { Test }\end{array}$} & \multicolumn{2}{|c|}{$2 \mathrm{Hrs}}$. & \multicolumn{2}{|c|}{$6 \mathrm{Hrs.}$} & \multicolumn{2}{|c|}{$12 \mathrm{Hrs}}$. & \multicolumn{2}{|c|}{16 Hrs. } & \multicolumn{2}{|c|}{24 Hrs. } \\
\hline & & B. & N. & B. & N. & B. & N. & B & N. & B. & N. \\
\hline A 1 & 5 & 0 & + & 0 & + & 0 & ++ & 0 & ++ & 0 & ++ \\
\hline $\mathrm{C} 2$ & 5 & 0 & + & 0 & + & 0 & + & 0 & ++ & + & ++ \\
\hline C 3 & 5 & 0 & + & 0 & + & 0 & + & + & ++ & ++ & ++ \\
\hline A 4 & 5 & 0 & + & 0 & $+t$ & 0 & ++ & 0 & ++ & ++ & ++ \\
\hline A 5 & 5 & 0 & + & 0 & + & 0 & ++ & 0 & ++ & ++ & ++ \\
\hline $\mathrm{C} 6$ & 10 & 0 & + & 0 & + & 0 & ++ & 0 & ++ & ++ & ++ \\
\hline 07 & 10 & 0 & + & 0 & + & 0 & + & 0 & ++ & ++ & ++ \\
\hline C 8 & 5 & 0 & + & 0 & $+t$ & ++ & ++ & $+t$ & ++ & ++ & ++ \\
\hline A II & 10 & 0 & + & 0 & + & 0 & + & 0 & + & ++ & ++ \\
\hline A I 2 & 5 & 0 & + & 0 & + & 0 & + & 0 & + & ++ & ++ \\
\hline
\end{tabular}

* In this and the following tables $B$, signifies biuret test; 0 , negative; + positive; $\mathrm{N}$, ninhydrin test; $\mathrm{C}$, pregnancy urines; and $\mathrm{A}$, the urine from males. All urines were incubated at $37.5 \mathrm{C}$.

2. Preparation of the Urine: The urines were obtained immediately after voiding and examined for albumin by the biuret test. If positive, they were made negative by the following method: Fifteen cubic centimeters of urine were placed in a well-stoppered bottle and shaken for ten minutes with $0.3 \mathrm{gm}$. kaolin; it was then filtered, and tested again. The shaking process was repeated till the biuret test was negative. Attempts to shake the urine with animal charcoal obtained from several different sources were not satisfactory, inasmuch as it was necessary to keep increasing the amount of urine used and a longer time was consumed to render the urine negative. Ten c.c. of the negative urine was neutralized to litmus with 2 per cent. sodium carbonate solution, if acid, or with 1 per cent. acetic acid, if alkaline.

3. The Technic of the Test: Ten c.c. prepared urine and $0.2 \mathrm{gm}$. of 
Table 2.-The Value of the Test in Pregnancy*

\begin{tabular}{|c|c|c|c|c|c|c|c|c|c|}
\hline \multirow{2}{*}{$\begin{array}{l}\text { Speci- } \\
\text { men } \\
\text { Number }\end{array}$} & \multirow{2}{*}{ Diagnosis } & \multirow{2}{*}{$\begin{array}{l}\text { C.c. } \\
\text { Each } \\
\text { Test }\end{array}$} & \multirow{2}{*}{$\begin{array}{c}\text { Hours } \\
\text { Incuba- } \\
\text { tion }\end{array}$} & \multicolumn{2}{|c|}{$\begin{array}{c}\text { Control (1) } \\
\text { Urine }\end{array}$} & \multicolumn{2}{|c|}{$\begin{array}{l}\text { Urine and } \\
\text { Placenta }\end{array}$} & \multicolumn{2}{|c|}{$\begin{array}{c}\text { Control (2) } \\
\text { Urine }\end{array}$} \\
\hline & & & & B. & N. & B. & N. & B. & N. \\
\hline 1 & Male-pneumonia.. & $\mathbf{5}$ & 12 & 0 & + & 0 & ++ & 0 & + \\
\hline 2 & Pregnancy..... & 5 & 16 & 0 & ++ & 0 & $+t$ & 0 & ++ \\
\hline 3 & Pregnancy......... & 5 & 16 & 0 & + & + & ++ & + & ++ \\
\hline 4 & Male-nephritis.... & 5 & 12 & 0 & ++ & 0 & ++ & 0 & ++ \\
\hline 5 & Male-carditis...... & 5 & 12 & 0 & ++ & 0 & ++ & 0 & ++ \\
\hline 6 & Pregnancy............. & 5 & 12 & 0 & + & 0 & ++ & 0 & ++ \\
\hline 7 & Pregnaney............ & 5 & 12 & 0 & ++ & 0 & ++ & 0 & ++ \\
\hline 8 & Pregnancy........ & 5 & 12 & 0 & ++ & ++ & ++ & 0 & ++ \\
\hline 9 & Pregnancy........... & 5 & 16 & 0 & + & 0 & + & + & ++ \\
\hline 10 & Pregnancy......... & 5 & 16 & 0 & + & 0 & + & + & ++ \\
\hline 11 & Male-nephritis..... & 10 & 16 & 0 & + & 0 & ++ & + & $+t$ \\
\hline 12 & Male-nephritis.... & 10 & 16 & 0 & + & 0 & + & 0 & + \\
\hline 13 & Pregnancy......... & 10 & 16 & 0 & + & 0 & + & ++ & ++ \\
\hline 14 & Pregnancy............ & 10 & 16 & 0 & ++ & ++ & + & 0 & ++ \\
\hline 15 & Pregnancy........... & 10 & 16 & 0 & + & + & ++ & 0 & ++ \\
\hline 16 & Pregnancy........... & 10 & 16 & 0 & + & 0 & $+t$ & 0 & ++ \\
\hline 17 & Pregnancy........... & 10 & 16 & $\mathbf{0}$ & + & 0 & + & + & + \\
\hline 18 & Pregnancy........... & 10 & 16 & 0 & + & + & ++ & 0 & + \\
\hline 19 & Male-pneumonia.. & 10 & 16 & 0 & + & 0 & + & + & ++ \\
\hline 20 & Pregnancy............ & 10 & 16 & 0 & + & 0 & + & + & ++ \\
\hline 21 & Pregnancy.......... & 10 & 18 & 0 & + & 0 & ++ & 0 & ++ \\
\hline 22 & Pregnancy........... & 10 & 18 & $\mathbf{0}$ & + & 0 & $+t$ & ++ & ++ \\
\hline 23 & Pregnancy......... & 5 & 24 & 0 & + & ++ & ++ & + & ++ \\
\hline 24 & Pregnancy............ & 5 & 24 & 0 & + & + & ++ & + & ++ \\
\hline 25 & Pregnancy........... & 10 & 24 & 0 & + & + & ++ & ++ & ++ \\
\hline 26 & Male-healthy........ & 10 & 24 & 0 & + & + & ++ & + & ++ \\
\hline $2 \pi$ & Pregnancy............. & 10 & 24 & 0 & + & 0 & + & + & ++ \\
\hline 28 & Pregnancy............. & 10 & 24 & 0 & + & + & ++ & t & ++ \\
\hline 29 & Pregr.ancy............ & 10 & 18 & 0 & + & 0 & + & 0 & + \\
\hline 30 & Pregnancy............. & 10 & 18 & 0 & + & + & + & + & + \\
\hline 31 & Pregnancy............. & 10 & 18 & 0 & ++ & + & ++ & 0 & ++ \\
\hline 32 & Pregnancy............. & 10 & 18 & $\mathbf{0}$ & + & + & ++ & $+t$ & ++ \\
\hline 33 & Pregnancy............. & 10 & 18 & $\mathbf{0}$ & + & 0 & + & + & ++ \\
\hline 34 & Male-healthr........ & 5 & 18 & 0 & + & 0 & + & + & + \\
\hline 35 & $\begin{array}{l}\text { Female-Ca. breast; } \\
\text { not pregnant...... }\end{array}$ & 5 & 18 & 0 & + & 0 & $+t$ & + & ++ \\
\hline
\end{tabular}

* In addition to the symbols explained in the footnote to Table 1 , in this and the following tables Ca. signifles carcinoma; (1), before incubation; (2), after incubation. 
Table 2--The Value of the Test in Pregnancy*-(Continued)

\begin{tabular}{|c|c|c|c|c|c|c|c|c|c|}
\hline \multirow{2}{*}{$\begin{array}{c}\text { Spect. } \\
\text { men } \\
\text { Number }\end{array}$} & \multirow{2}{*}{ Diagnosis } & \multirow{2}{*}{$\begin{array}{l}\text { C.c. } \\
\text { Each } \\
\text { Test }\end{array}$} & \multirow{2}{*}{$\begin{array}{c}\text { Hours } \\
\text { Incuba- } \\
\text { tion }\end{array}$} & \multicolumn{2}{|c|}{$\underset{\text { Orine }}{\text { Control (1) }}$} & \multicolumn{2}{|c|}{$\begin{array}{l}\text { Urine and } \\
\text { Placenta }\end{array}$} & \multicolumn{2}{|c|}{$\underset{\text { Urine }}{\text { Control (2) }}$} \\
\hline & & & & B. & N. & B. & N. & B. & N. \\
\hline 36 & Male-healthy....... & 10 & 18 & 0 & + & 0 & + & + & ++ \\
\hline 37 & Pregnaney........... & 10 & 16 & 0 & + & + & ++ & 0 & ++ \\
\hline 38 & Male-healthy... & 5 & 16 & 0 & + & ++ & ++ & 0 & ++ \\
\hline 39 & Pregnancy....... & 5 & 16 & $\boldsymbol{v}$ & + & 0 & + & 0 & + \\
\hline 40 & $\begin{array}{r}\mathbf{M}_{\text {ale }}-\text { ulcer of stom.l } \\
\text { ach................... }\end{array}$ & 10 & 16 & 0 & + & 0 & + & ++ & ++ \\
\hline 41 & Pregnancy........... & 10 & 16 & 0 & + & + & + & + & + \\
\hline 42 & Male-healthy....... & 10 & 16 & 0 & ++ & 0 & ++ & 0 & ++ \\
\hline 43 & Pregnancy........... & 10 & 20 & 0 & + & ++ & ++ & ++ & ++ \\
\hline 44 & Pregnancy........... & 10 & 20 & 0 & + & ++ & ++ & ++ & ++ \\
\hline 45 & Male-healthy....... & 10 & 20 & 0 & + & 0 & + & + & + \\
\hline 46 & Pregnancy...... & 10 & 16 & 0 & + & + & + & 0 & ++ \\
\hline 47 & Pregnancy........... & 10 & 16 & 0 & + & 0 & + & 0 & + \\
\hline 48 & Pregnancy........ & 5 & 16 & 0 & + & + & + & $\mathbf{0}$ & + \\
\hline 49 & Pregnancy............ & 10 & 18 & 0 & ++ & + & + & + & ++ \\
\hline 50 & Pregnancy........... & 10 & 18 & 0 & $+t$ & + & + & + & ++ \\
\hline 51 & Pregnancy............ & 10 & 18 & 0 & + & 0 & + & ++ & ++ \\
\hline 52 & Male-healthy....... & 10 & 16 & 0 & + & 0 & + & 0 & ++ \\
\hline 53 & Male-healthy....... & 10 & 16 & 0 & + & 0 & + & 0 & ++ \\
\hline 54 & Pregnancy............ & 10 & 16 & 0 & + & $\div+$ & ++ & 0 & ++ \\
\hline 55 & Pregnaney........... & 10 & 16 & 0 & 0 & ++ & ++ & 0 & ++ \\
\hline 56 & $\begin{array}{c}\text { Female }- \text { general } \\
\text { cancer, not preg- } \\
\text { nant.................. }\end{array}$ & 10 & 20 & 0 & ++ & 0 & ++ & + & ++ \\
\hline 57 & $\begin{array}{c}\text { Ca. uterus; not } \\
\text { pregnant............ }\end{array}$ & 10 & 20 & $\mathbf{0}$ & + & + & + & ++ & ++ \\
\hline 58 & Male-healthy.... & 10 & 18 & 0 & + & + & + & ++ & ++ \\
\hline 59 & Pregnancy........... & 10 & 18 & 0 & $+t$ & ++ & ++ & ++ & ++ \\
\hline 60 & Pregnancy............ & 10 & 18 & 0 & + & + & ++ & + & ++ \\
\hline 61 & Male-Ca........... & 10 & 16 & 0 & + & 0 & + & + & + \\
\hline 62 & Male-Ca............ & 10 & 16 & 0 & ++ & 0 & + & 0 & ++ \\
\hline 63 & Male-Ca. ........... & 5 & 18 & 0 & $+t$ & + & ++ & ++ & ++ \\
\hline 64 & Male-Ca........... & 5 & 18 & $n$ & + & 0 & ++ & ++ & ++ \\
\hline 65 & Male-Ca..... & 5 & 18 & 0 & + & + & $+\div$ & ++ & ++ \\
\hline 66 & Male-Ca............ & 10 & 18 & 0 & $+t$ & 0 & + & ++ & ++ \\
\hline 67 & Male-Ca........... & 10 & 18 & 0 & + & 0 & + & + & ++ \\
\hline
\end{tabular}

* In addition to the symbols explained in the footnote to Table 1 , in this and the fol lowing tables Ca. signifles carcinoma: (1), before incubation; (2), after incubation. 
dried placenta (or dried carcinoma) were thoroughly mixed by vigorous shaking and toluene added to cover the mixture completely. The toluene was used to restrict bacterial growth and to prevent drying. These mixtures were incubated at $37.5 \mathrm{C}$. for twelve hours, and then one-half was drawn off, filtered and tested by the biuret reaction. The remainder was incubated for from four to twelve hours longer and again tested. The best results were obtained by the longer incubation (Table 1). Control tests were carried out with urine alone and with substrate in distilled water. The control urines were always positive to the ninhydrin reagent. All green and blue in the biuret test were considered negative. A positive test varied from purple to lilac.

Table 3.-Pregnancy Urines Incubated with Placental and Cancer Substrates

\begin{tabular}{|c|c|c|c|c|c|c|c|c|c|c|}
\hline \multirow{2}{*}{$\begin{array}{l}\text { Specimen } \\
\text { Number }\end{array}$} & \multirow{2}{*}{$\begin{array}{l}\text { C.c. } \\
\text { Each } \\
\text { T'est }\end{array}$} & \multirow{2}{*}{$\begin{array}{l}\text { Hours } \\
\text { Incuba- } \\
\text { tion }\end{array}$} & \multicolumn{2}{|c|}{$\begin{array}{c}\text { Control (1) } \\
\text { Uriue }\end{array}$} & \multicolumn{2}{|c|}{$\begin{array}{l}\text { Urine and } \\
\text { Placenta }\end{array}$} & \multicolumn{2}{|c|}{$\begin{array}{l}\text { Urine and } \\
\text { Carcinoma }\end{array}$} & \multicolumn{2}{|c|}{$\underset{\text { Urine }}{\text { Control (2) }}$} \\
\hline & & & B. & N. & B. & N. & B. & N. & B. & N. \\
\hline 41 & 10 & 16 & 0 & + & + & + & 0 & + & + & + \\
\hline 43 & 10 & 20 & + & ++ & ++ & ++ & + & ++ & ++ & ++ \\
\hline 44 & 10 & 20 & 0 & + & ++ & ++ & 0 & ++ & ++ & ++ \\
\hline 46 & 10 & 16 & 0 & + & + & + & 0 & + & 0 & ++ \\
\hline 47 & 10 & 16 & 0 & + & 0 & + & + & ++ & 0 & + \\
\hline 48 & $\overline{5}$ & 16 & 0 & + & + & + & 0 & + & 0 & + \\
\hline 49 & 10 & 18 & 0 & ++ & + & + & 0 & + & + & ++ \\
\hline 50 & 10 & 18 & 0 & ++ & + & + & + & + & + & ++ \\
\hline 51 & 10 & 18 & 0 & + & 0 & + & 0 & + & ++ & ++ \\
\hline 54 & 10 & 16 & 0 & + & ++ & ++ & 0 & + & 0 & ++ \\
\hline
\end{tabular}

From Table 1 it is evident that the minimal period of incubation should not be less than twelve hours, which is considerably longer than noted by Kiutsi. He obtained his results in two hours. It was noteworthy that within twenty-four hours all the specimens except one became positive. The ninhydrin reaction became more positive as the period of incubation increased.

Forty-one pregnancy urines were incubated with placenta, as noted in Table 2, and only twenty-four, or 58.9 per cent., gave a positive reaction and seventeen, or 41 per cent., were negative. Of twenty-six specimens of urine from nonpregnant women examined with placenta, six, or 23 per cent., were positive and twenty, or 77 per cent., were negative. The negative results appeared to be more important than the positive findings.

The next step was to determine the specificity of the test by incubating pregnancy urines with placental and cancer substrates and then treating cancer urines the same way. 
Ten pregnancy urines were incubated with cancer tissue and three gave a positive result, while seven gave a negative restult. This again speaks for a greater value of negative results than of positive reports.

In malignancy with cancer substrate ten urines were used. These cases were positively carcinomatous, as shown by pathologic reports. In this study four were positive and six were negative. These were incubated at the same time with placental tissue and three, or 30 per cent., gave a positive reaction, while seven, or 70 per cent., gave a negative result.

TABLE 4.-Cancer Urines Incubated with Placental and Cancer SubStrates

\begin{tabular}{|c|c|c|c|c|c|c|c|c|c|c|c|}
\hline \multirow{2}{*}{$\begin{array}{c}\text { Speci- } \\
\text { mien } \\
\text { No. }\end{array}$} & \multirow{2}{*}{$\begin{array}{c}\text { C.c. } \\
\text { Each } \\
\text { Test }\end{array}$} & \multirow{2}{*}{$\begin{array}{l}\text { Hours } \\
\text { Incuba- } \\
\text { tion }\end{array}$} & \multicolumn{2}{|c|}{$\begin{array}{c}\text { Control (1) } \\
\text { Urines }\end{array}$} & \multicolumn{2}{|c|}{$\begin{array}{l}\text { Urine and } \\
\text { Placenta }\end{array}$} & \multicolumn{2}{|c|}{$\begin{array}{l}\text { Urine and } \\
\text { Carcinoma }\end{array}$} & \multicolumn{2}{|c|}{$\begin{array}{c}\text { Control (2) } \\
\text { Urine }\end{array}$} & \multirow[t]{2}{*}{ Diagnosis } \\
\hline & & & B. & N. & B. & N. & B. & N. & B. & N. & \\
\hline 35 & 5 & 18 & 0 & + & 0 & + & 0 & + & + & ++ & Ca. breast \\
\hline 56 & 10 & 20 & 0 & ++ & 0 & ++ & + & + & + & ++ & General Ca.-woman, \\
\hline 57 & 10 & 20 & 0 & + & + & + & + & ++ & ++ & ++ & Ca. uterus, not preg. \\
\hline 61 & 10 & 16 & 0 & + & 0 & + & 0 & + & + & ++ & Ca. stomach-male \\
\hline 62 & 10 & 16 & 0 & ++ & 0 & + & 0 & ++ & 0 & ++ & Ca. stomach-male \\
\hline 63 & 5 & 18 & 0 & ++ & + & ++ & + & ++ & ++ & +-1 & Ca. pancreas-male \\
\hline 64 & 5 & 18 & 0 & + & 0 & ++ & + & + & ++ & ++ & Ca. stomach - male \\
\hline 65 & 5 & 18 & 0 & + & + & ++ & 0 & + & ++ & ++ & Ca. stomach - male \\
\hline 66 & 10 & 18 & 0 & ++ & 0 & + & 0 & + & ++ & ++ & Ca. breast \\
\hline 67 & 10 & 18 & 0 & + & 0 & + & 0 & + & + & ++ & Ca. stomach - male \\
\hline
\end{tabular}

Of interest was the observation that pregnancy urines reacted with cancer tissue the same way that the cancer urines reacted with the placental substrate.

The biuret reaction was always negative before incubation in both the test and control urines. The reactions after incubation in the control urines gave the following conflicting results:

Total number control urines (nonpregnant patients) (includ-

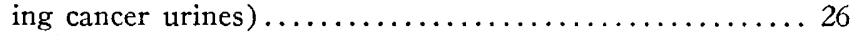

Positive biuret reactions after incubation.............. 17

Negative biuret reactions after incubation.............. 9

Total number pregnancy urine controls................. 41

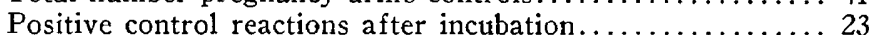

Negative control reactions after incubation............. 18

The results so far obtained in these studies do not coincide with conclusions drawn by the originator of the test. We are inclined to believe that negative results alone should be used as corroborative diagnosis.

223 East Seventy-Second Street. 